Thorax (1972), 27, 586.

\title{
Silent lower aortic obstruction
}

\author{
F. D. SALA M A ${ }^{1}$ and C. E. D R EW \\ Department of Thoracic Surgery, Westminster Hospital, London S.W.1
}

Three cases of lower aortic obstruction are described in which the diagnosis was made at operation.

Profound hypothermia with circulatory arrest was used for replacement of the mitral valve by a Starr Edwards prosthesis. Femoral perfusion was used and the diagnosis was made in the first case only because the rectal temperature fell precipitously during cooling, while the temperature in the upper part of the body was slow to fall. In this case disobliteration was not carried out, but in two further cases this was done through a bilateral femoral arteriotomy using Fogarty catheters.

All cases were seen during a period of 18 months among 35 mitral valve replacements.

Silent lower aortic obstruction may not therefore be a rare condition and might be responsible for hypotension during normothermic cardiopulmonary bypass when the femoral artery is used for cannulation. If the aortic root is used, the condition will not be discovered.

If exercise tolerance is greatly improved after successful operation symptoms of the obstruction may become manifest, and if further thrombosis occurs and symptoms are more acute they may be wrongly attributed to embolization from the valve replacement. Routine abdominal aortography during left heart studies should disclose a clinically silent obstruction.

Obstruation of the aortic bifurcation by an embolus is usually a dramatic event, well remembered by patient and doctor. However, the symptoms are sometimes sufficiently mild for the incident to pass unnoticed. Subacute and transitory cases have been described (Ewing, 1950 ; Read, Ball, and Rob, 1960). This paper describes three cases in which obstruction of the lower aorta was discovered on exposing the femoral anteries for cardiac bypass and valve replacement (Table).

\section{CASE REPORTS}

CASE 1 A 29-year-old woman was admitted for tonsillectomy in 1961 at which time she was found to have mitral regurgitation. For two years she had slight dyspnoea on exertion but she could climb three flights of stairs. Gradually she became more breathless. Cardiac catheterization in October 1966 and July 1968 revealed mitral regurgitation, tricuspid stenosis and regurgitation, and aortic regurgitation. She was in atrial fibrillation. By then she could do only a little housework without dyspnoea and spent much time in bed.

On 2 December 1968 operation was undertaken using profound hypothermia and lung perfusion (Drew, Keen, and Benazon, 1959). The heart was exposed through a median sternotomy. The left femoral artery was exposed, opened with free bleeding, and cannulated. Bypass and cooling were started. It was soon noticed that the rectal temperature fell rapidly 1Present address : St. George's Hospital, London S.W.1 and was well below both oesophageal and nasopharyngeal temperatures, suggesting that much of the pump output was circulating through the pelvic vessels. The mean radial artery pressure during perfusion was $40 \mathrm{mmHg}$ at a pump flow of $3.61 / \mathrm{min}$. Cooling to a nasopharyngeal temperature of $15^{\circ} \mathrm{C}$ took 77 minutes compared with the expected 25-35 minutes. 'Triple valve replacement using Starr-Edwards' prostheses was successfully completed with periods of perfusion between each valve insertion. The arterial cannula was then removed from the left femoral artery and placed in the ascending aorta. The mean radial artery pressure rose to $70 \mathrm{mmHg}$. Rewarming took 65 minutes because, although the nasopharyngeal temperature now rose rapidly, the rectal temperature was slow to respond (Fig. 1).

The patient had never complained of symptoms suggesting obstruction to the lower aorta. On discharge from hospital all peripheral pulses were palpable.

CASE 2 A 42-year-old woman was well until her third pregnancy in 1952 when she had an episode of haemoptysis and was found to have mitral stenosis. In 1962 she had a pulmonary embolus and was given anticoagulants. In March 1963 closed mitral valvotomy was carried out producing severe regurgitation. Following operation she developed atrial fibrillation, cardiac failure, and multiple pulmonary infarcts. She was maintained on digoxin, diuretics, and anticoagulants.

During the next six years there was progressive deterioration. Regurgitation and pulmonary hyper- 
T A B L E

\begin{tabular}{|c|c|c|c|c|c|c|c|c|c|c|c|c|c|c|c|}
\hline \multirow{3}{*}{$\begin{array}{l}\text { Case } \\
\text { No. }\end{array}$} & \multirow{3}{*}{$\begin{array}{l}\text { Age/ } \\
\text { Sex }\end{array}$} & \multirow{3}{*}{$\begin{array}{l}\text { Cardiac } \\
\text { Catheter }\end{array}$} & \multirow{3}{*}{$\begin{array}{c}\text { Date of } \\
\text { Operation }\end{array}$} & \multirow{3}{*}{$\begin{array}{c}\text { Preoper- } \\
\text { ative } \\
\text { Ischaemic } \\
\text { Symptoms }\end{array}$} & \multirow{3}{*}{$\begin{array}{l}\text { Atrial } \\
\text { Fibril- } \\
\text { lation }\end{array}$} & \multirow{3}{*}{$\begin{array}{l}\text { Preop. } \\
\text { Anti- } \\
\text { coagulant } \\
\text { Therapy }\end{array}$} & \multirow{3}{*}{$\begin{array}{c}\text { Condition } \\
\text { of } \\
\text { Peripheral } \\
\text { Pulses } \\
\text { Preoper- } \\
\text { atively }\end{array}$} & \multicolumn{6}{|c|}{ Perfusion } & \multirow{3}{*}{$\begin{array}{l}\text { Embo- } \\
\text { lectomy }\end{array}$} & \multirow{3}{*}{ Result } \\
\hline & & & & & & & & \multicolumn{3}{|c|}{ Cooling } & \multicolumn{3}{|c|}{ Rewarming } & & \\
\hline & & & & & & & & $\begin{array}{c}\text { Flow } \\
\text { (1/ } \\
\text { min) }\end{array}$ & $\begin{array}{l}\mathbf{B P} \\
(\mathbf{m m} \\
\mathbf{H g})\end{array}$ & $\begin{array}{l}\text { Time } \\
(\min )\end{array}$ & $\begin{array}{c}\text { Flow } \\
\text { (1/ } \\
\text { min) }\end{array}$ & $\underset{(\mathbf{H g})}{\mathbf{H g}}$ & $\begin{array}{l}\text { Time } \\
(\min )\end{array}$ & & \\
\hline 1 & $\begin{array}{c}29 \\
F\end{array}$ & $\begin{array}{ll}\text { Oct. } & 1966 \\
\text { July } & 1968\end{array}$ & $\begin{array}{l}\text { Dec. } 1968 \\
\text { Triple } \\
\text { valve } \\
\text { replace- } \\
\text { ment }\end{array}$ & None & Present & None & Present & $3 \cdot 6$ & 40 & 77 & $2 \cdot 6$ & 70 & 65 & $\begin{array}{l}\text { Not } \\
\text { performed }\end{array}$ & $\begin{array}{l}\text { All } \\
\text { pulses } \\
\text { present }\end{array}$ \\
\hline 2 & $\stackrel{42}{F}$ & $\begin{array}{l}\text { Dec. } 1969 \\
\text { Jan. } 1970\end{array}$ & $\begin{array}{l}\text { Feb. } 1970 \\
\text { Mitral } \\
\text { valve } \\
\text { replace- } \\
\text { ment }\end{array}$ & $\begin{array}{l}\text { Slight } \\
\text { coldness } \\
\text { of feet } \\
\text { appreci- } \\
\text { ated only } \\
\text { in retro- } \\
\text { spect } \\
\text { postop. }\end{array}$ & Present & 8 yr & $\begin{array}{l}\text { Present } \\
\text { (equivocal } \\
\text { evidence) }\end{array}$ & $3 \cdot 5$ & 80 & 29 & $3 \cdot 5$ & 80 & 40 & $\begin{array}{l}\text { Bilat. } \\
\text { femoral } \\
\text { arteriotomy } \\
\text { and extrac- } \\
\text { tion of clot, } \\
\text { by Fogarty's } \\
\text { catheter }\end{array}$ & $\begin{array}{l}\text { All } \\
\text { pulses } \\
\text { present. } \\
\text { Feet } \\
\text { felt } \\
\text { warmer }\end{array}$ \\
\hline 3 & $\begin{array}{l}53 \\
\mathbf{M}\end{array}$ & Apl. 1970 & $\begin{array}{l}\text { June } 1970 \\
\text { Mitral } \\
\text { valve } \\
\text { replace- } \\
\text { ment }\end{array}$ & $\begin{array}{l}\text { Severe } \\
\text { abdominal } \\
\text { pain and } \\
\text { rectal } \\
\text { bleeding } 4 \\
\text { mth preop. } \\
\text { Recovered } \\
\text { completely } \\
\text { ?embolus }\end{array}$ & Present & $5 \mathrm{mth}$ & $\begin{array}{l}\text { All present } \\
\text { initially. } \\
\text { Became } \\
\text { weak after } \\
\text { cardiac } \\
\text { catheteriza- } \\
\text { tion } 1 \text { mth } \\
\text { preop. }\end{array}$ & $3 \cdot 5$ & 80 & 31 & $3 \cdot 5$ & 80 & 35 & $\begin{array}{l}\text { Bilat. } \\
\text { femoral } \\
\text { arteriotomy } \\
\text { and extrac- } \\
\text { tion of clot } \\
\text { by Fogarty's } \\
\text { catheter }\end{array}$ & $\begin{array}{l}\text { All } \\
\text { pulses } \\
\text { present }\end{array}$ \\
\hline
\end{tabular}

tension became pronounced. She spent much of her time in bed. She was referred to Westminster Hospital for investigation in January 1970 . Two cardiac catheterizations in December 1969 and January 1970 were required to confirm the clinical diagnosis. During the procedures both femoral arteries were punctured by a Seldinger needle for left heart studies.

On 23 February 1970 operation was undertaken using profound hypothermia and lung perfusion. The heart was exposed through a median sternotomy. The left and then the right femoral arteries were exposed and were patent, but the flow was poor from both.
Fogarty catheters were passed up both arteries and a large amount of old organized and recent clot was extracted from the lower aorta. This clearance was followed by brisk bleeding. Cooling and rewarming at pump flows of $3.51 / \mathrm{min}$ took 29 minutes and 40 minutes respectively. The mean radial artery pressure during perfusion was $80 \mathrm{mmHg}$. Mitral valve replacement using a Starr-Edwards prosthesis was successfully completed.

The patient at no time had symptoms suggestive of aortic obstruction. Unfortunately there is no documentation of the state of her peripheral pulses beyond

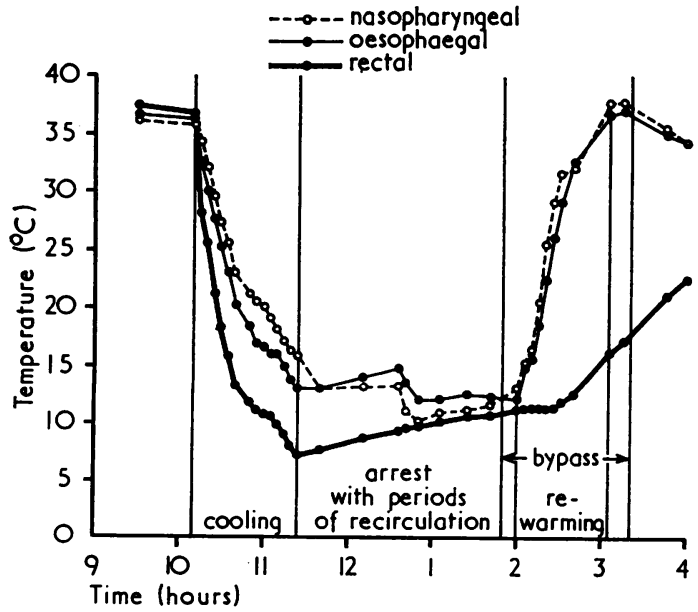

FIG. 1. Case 1. See text.

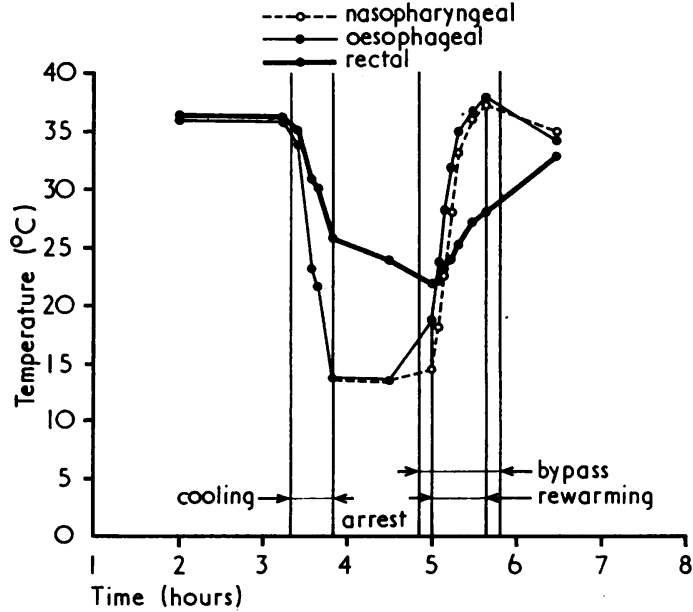

FIG. 2. Case 2. See text. 
December 1963 when they were normal. On discharge from hospital all peripheral pulses were palpable. She noticed that her feet were warm for the first time for many years.

CASE 3 A 53-year-old man complained of increasing dyspnoea for three years. One year previously he had had a bout of extreme fatigue and became markedly breathless. At this time he was found to have mitral stenosis and regurgitation and was in atrial fibrillation. He responded well to, and was maintained on, digoxin and diuretics. In January 1970 he developed an attack of severe abdominal pain and rectal bleeding. He was admitted to hospital and lost consciousness for a brief period. There were no localizing signs and the patient recovered completely. The attack was attributed to embolism and the patient was given anticoagulants. His condition gradually deteriorated and he became more breathless on slight exertion. Cardiac catheterization, including left femoral puncture, was performed in April 1970, confirming the presence of a double mitral lesion and mild aortic regurgitation. After the procedure both femoral pulses were found to be weak.

On 4 June 1970 operation was undertaken using profound hypothermia and lung perfusion. It was noticed that the right femoral pulse was very weak and the left was absent. Both arteries were exposed and found to be patent. There was no flow in the left femoral artery and the right showed poor flow. There was atheroma in both arteries. Fogarty catheters were passed up both arteries and large clots were removed from the level of the aortic bifurcation. Most of the clot was old but a small amount was recent. Cooling and rewarming at pump flows of $3.51 / \mathrm{min}$ took 31 and 35 minutes respectively. Mean radial artery pressure during perfusion was $80 \mathrm{mmHg}$. Mitral valve replacement using a Starr-Edwards valve was successfully completed.

The patient at no time had any symptoms of ischaemia to the lower limbs. On discharge from hospital all peripheral pulses were palpable.

\section{DISCUSSION}

Ninety-three per cent of peripheral emboli originate in the heant (Young, Humphries, DeWolfe, and LeFevre, 1963). Rheumatic mitral disease, especially with atrial fibrillation, is the usual association. In a series of 393 emboli occurring in rheumatic heart patients, saddle aortic embolism occurred in $11 \%$ (Daley et al., 1951). Belcher and Somerville (1955) found a saddle embolus incidence of $7 \%$ in 430 cases of embolic complications of mitral stenosis.

Various modes of presentation are described (Flanc, 1968). Read et al. (1960) described a subacute group in which symptoms were initially mild and the viability of the limbs was not immediately threatened. However, the limbs showed variable degrees of ischaemia which led to the correct diagnosis in retrospect several months, and, in the longest case, three years, after onset of the symptoms.

In our cases, several points are noteworthy. The complete absence of any symptoms is striking. The most probable explanation is that a small embolus may have lodged at the bifurcation of the aorta without causing significant obstruction. Secondary thrombosis may then have steadily occluded the aorta, by which time the collateral circulation gradually had time to develop (Read $e t$ al., 1960). Premonitory symptoms in the form of abdominal cramps with nausea and vomiting have been described (Herrman, Willis, McKinley, and Karotkin, 1943) and attributed to a temporary closure of mesenteric and renal vessels by the migrating embolus. In the third case, the attack of abdominal pain and rectal bleeding in January 1970 must be considered in this context. In the other two cases, there were no preoperative symptoms which could have suggested the presence of aortic obstruction.

The presence of the peripheral pulses is an indication of a strongly developed collateral circulation (Eastcott, 1969). Friedman, Holling, and Roberts (1964) found six cases with present distal pulses in 43 patients with lower aortic and common iliac obstruction. Although the condition of the pulses in our second case was not satisfactorily documented before the operation, the fact that puncture of both femoral arteries for left heart catheterization was accomplished without any difficulty indicates that at least the femoral pulses were present. The absence of intermittent claudication can be explained partly by the free collateral circulation. However, the extreme disability of these patients prevented exercise which otherwise would have produced claudication.

Our first case is of particular interest because, in spite of apparently satisfactory bleeding when the artery was opened for cannulation, subsequent events indicated that much of the pump output was diverted into the pelvic vessels. Figure 1 illustrates the temperature chart of this case. There is a precipitous drop of rectal temperature below both oesophageal and nasopharyngeal temperatures, in striking contrast to normal, as illustrated in Figure 2. Moreover, with comparable pump flows, cooling took more than double the usual time, and the radial antery blood pressure during perfusion was low. The explanation of these events is the presence of an obstruction in the lower aorta, forcing blood into a well developed collateral circulation. The level of the obstruction was most probably at the aortic bifurcation, as suggested by 
our experience in the next two cases. Despite moving the arterial cannula into the ascending aorta, rewarming took the unusually long time of 65 minutes to allow the rectal temperature to reach a reasonable level. This case could explain certain instances during normothermic cardio-pulmonary bypass with femoral cannulation when blood pressure during perfusion is low for no obvious reason. Osborn (1967) discussed the causes of low pressure during perfusion and stated that no cause could be found once in every 50 perfusions. Low arterial pressure during perfusion is certainly detrimental, and Doberneck, Reiser, and Lillehei (1962) showed that the incidence of acute renal failure after open heart surgery closely corresponded to hypotension. Schmutzer (1959) described a case of a 38-year-old woman with aortic stenosis. When cardiopulmonary bypass was started, her blood pressure fell alarmingly but reverted to normal when bypass was stopped. This recurred every time bypass was restarted and eventually the procedure was abandoned. He assumed that the patient had Takayasu's disease of the aortic arch, with three valvular thrombi obstructing the origins of the great vessels when the blood flow in the aorta was reversed. Lower aortic obstruction or a limited dissection would be a more plausible explanation.

Our three cases support the experience of others (Brock, 1962 ; Haimovici, 1959 ; Olwin, Dye, and Julian, 1953 ; Spencer and Eiseman, 1964) that late arterial embolectomy is a useful procedure and is often successful. Perlow (1959) noticed that limbs surviving aortic occlusion with conservative treatment developed variable degrees of ischaemia. Krause, Cranley, Baylon, and Strasser (1959) contend that as long as there is no obvious tissue death, no time limit should be set for the operation. Fogarty's catheter (Fogarty and Cranley, 1965) proved effective in extracting old clot, confirming the experience of others (Cranley et al., 1964).

The influence of age on the efficiency of collateral circulation is well illustrated. The first patient, a young woman of 29, had sufficient collaterals to keep a reasonable lower limb circulation. The second case, a 42-year-old woman, although unaware of any ischaemic symptoms before the operation, realized that her feet were unduly cold compared with the warmth she felt postoperatively, indicating a minor degree of ischaemia. The third case, a 53-year-old man, and the only one of our cases who had atheromatous changes in his arteries, developed thrombosis of the aorta after femoral puncture. In his case, partial lower aortic obstruction must have been present, judging by the amount of old clot removed, setting the stage for secondary thrombosis. The disappearance of his pulses after the incident indicates a meagre collateral circulation.

Anticoagulants have been proved to reduce the incidence of peripheral embolism in rheumatic heart disease (Szekely, 1964), especially after cardiac operations (Peterson, Fisher, Reis, and Morrow, 1969). Our second and third cases received anticoagulants for eight years and five months respectively before operation. It is uncertain, due to lack of symptoms, whether they developed aortic emboli while on anticoagulant therapy. It is possible that the episodes necessitating the institution of anticoagulants in both cases coincided with a small embolus to the aortic bifurcation.

Routine abdominal aortography during left heart studies in mitral valve disease should identify such cases. It carries no added risk. The discovery of an unexpected lower aortic obstruction might influence the surgeon to choose the ascending aorta rather than the femoral antery for arterial return. Alternatively, if he prefers the femoral route, he would have ample angiographic evidence as to the state of the lower aorta and its branches and can plan the necessary disobliteration accordingly. If femoral obstruction is discovered at operation, with no angiographic evidence beforehand, it is wise to explore both femoral arteries simultaneously to obtain clearance of the aortic bifurcation.

There is a theoretical danger that retrograde flow in the femoral artery after cannulation might scatter residual clot and produce embolization elsewhere, but there was no evidence of this in the two cases in which clot extraction was undertaken.

The three cases described were seen during a period of 18 months, during which 35 mitral valve replacements were carried out. This suggests that silent lower aortic obstruction is not a rare condition. It will not be discovered at operation if the root of the aorta is used for perfusion.

The first case was diagnosed only because profound hypothermia was used and attention was drawn to the possibility by the bizarre temperature recordings.

It is likely that many cases are not diagnosed before surgery. If surgery is successful, exercise tolerance is increased and intermittent claudication or other symptoms may be complained of for the first time, particularly if further clot is added to the old. The occurrence of these symptoms, particularly if acute, may be wrongly attributed to embolization from a prosthetic valve. 


\section{REFERENCES}

Belcher, J. R., and Somerville, W. (1955). Systemic embolism and left auricular thrombosis in relation to mitral valvotomy. Brit. med. J., 2, 1000.

Brock, R. (1962). Late arterial embolectomy. J. cardiovasc. Surg. (Torino), 3, 39.

Cranley, J. J., Krause, R. J., Strasser, E. S., Hafner, C. D., and Fogarty, T. J. (1964). Peripheral arterial embolism: changing concepts. Surgery, 55, 57.

Daley, R., Mattingly, T. W., Hold, C. L., Bland, E. F., and White, P. D. (1951). Systemic arterial embolism in rheumatic heart disease. Amer. Heart. J., 42, 566.

Doberneck, R. C., Reiser, M. P., and Lillehei, C. W. (1962). Acute renal failure after open-heart surgery utilizing extracorporeal circulation and total body perfusion: Analysis of one thousand patients. J. thorac. cardiovasc. Surg., 43, 441.

Drew, C. E., Keen, G., and Benazon, D. B. (1959). Profound hypothermia. Lancet, 1, 745.

Eastcott, H. H. G. (1969). Arterial Surgery, pp. 57 and 261. Pitman Medical Publications, London.

Ewing, M. R. (1950). Aortic embolectomy. Brit. J. Surg., $38,44$.

Flanc, C. (1968). Saddle embolism of the aorta. Aust. N.Z. J. Surg., 37, 384.

Fogarty, T. J., and Cranley, J. J. (1965). Catheter technic for arterial embolectomy. Ann. Surg., 161, 325.

Friedman, S. A., Holling, H. E., and Roberts, B. (1961). Etiologic factors in aortoiliac and femoropopliteal vascular disease: the Leriche syndrome. New Engl. J. Med., 271, 1382.

Haimovici, H. (1959). Late arterial embolectomy. Surgery, 46, 775 .
Herrmann, G. R., Willis, J. G., McKinley, W. F., and Karotkin, L. (1943). Embolism and secondary thrombosis of the bifurcation of the aorta. Amer. Heart. $J$, 26, 180.

Krause, R. J., Cranley, J. J., Baylon, L. M., and Strasser, E. S. (1959). Recent advancements in the treatment of peripheral arterial embolism. Arch. Surg., 79, 285.

Olwin, J. H., Dye, W. S., and Julian, O. C. (1953). Late peripheral arterial embolectomy. Arch. Surg., 66, 480.

Osborn, J. J. (1967). Cardiac Surgery, edited by John C. Norman, p. 91. Meredith Publishing Company, New York.

Perlow, S. (1959). Embolism at bifurcation of aorta. J. Amer. med. Ass., 171, 41.

Peterson, L. M., Fisher, R. D., Reis, R. L., and Morrow, A. G. O (1969). Cardiac operations in patients with left atrial thrombus. Incidence and prevention of postoperative embolism. Ann. thorac. Surg., 8, 402.

Read, A. E. A., Ball, K. P., and Rob, C. G. (1960). Embolic occlusion of the aorta in patients with mitral stenosis. Quart. J. Med., 29, 459.

Schmutzer, K. J. (1959). Intra- und postoperative Probleme bei der Anwendung des extrakorporalen Kreislaufes. Langenbecks Arch. klin. Chir., 292, 666.

Spencer, F. C., and Eiseman, B. (1964). Delayed arterial embolectomy-a new concept. Surgery, 55, 64.

Szekely, P. (1964). Systemic embolism and anticoagulant prophylaxis in rheumatic heart disease. Brit. med.J., 1, 1209.

Young, J. R., Humphries, A. W., DeWolfe, V. G., and LeFevre, F. A. (1963). Peripheral arterial embolism. J. Amer. med. Ass., 185, 621 . 